SHS Web of Conferences 10, 00044 (2014)

DOI: $10.1051 /$ shsconf/20141000044

C Owned by the authors, published by EDP Sciences, 2014

\title{
Relationships between children and their grandparents and importance of older generations in lives of todays'families
}

\author{
L. Stasova and E. Krisikova \\ University of Hradec Kralove, Czech Republic
}

\begin{abstract}
The article deals with the issue of relationships among contemporary generations. It is devoted to the specific communication and relationships development between today's children and their grandparents. What is the role played by grandparents in lives of their grandchildren? Is the generation gap so powerful to destroy the traditionally strong relationships in families? Our text stresses the importance of an intergenerational socializations influence and its positives for individuals and the whole family system.

The article is based on the empirical survey among the 202 respondents in the age group 12-17. The data tried to show that there are differences in relationships in families where the generations are living together and the families with separate living of generations. However, this presumption was not confirmed and our data show that there is no difference in frequency and quality of relationships between both groups of families. The important question is, if the face-to-face communication has been replaced by other means of communication, especially through modern media, or not. The data show the intensity and content of intergenerational meeting in family. It brings some view on the attitudes of young Czech people towards their grandparents. The results show the mostly positive intergenerational relationships and the value of older generations for young people. Interesting are expressions of appreciation of grandmothers and grandfathers from their grandchildren. The relationships to grandparents are mostly influenced by the whole family climate and are closely connected with the parental attitudes toward the older generations.
\end{abstract}

\section{Introduction}

Society as a whole is made up of individuals of different ages with different life experiences and approach to life. Such groups of contemporaries are known as generation and they are linked not only to belonging to a certain age group, but also with some cultural background and historical events that framed their lives. Within the family cycle, those who are together in some stage of family life are defined as generations. We talk about a generation of children, parents' generation and generation of grandparents. With a membership to the generations, there are also connected certain social roles and social status, which are subjected to the changing society and culture.

This text focuses on the relationships among generations within the family cycle and it is about children, parents and grandparents. It asks a question in what current grandparents are important for today's generation of children and what role they play in contemporary family life. These questions are crucial as considerable individualization and atomization of family life and disruption of some

This is an Open Access article distributed under the terms of the Creative Commons Attribution License 4.0, which permits unrestricted use, distribution, and reproduction in any medium, provided the original work is properly cited. 
traditional family ties takes place nowadays. Specific attention is paid to the relationships between generations of children and grandparents; these relationships may be affected by generational gap and generational conflict.

\section{What role can grandparents play in the family system?}

The specific role of grandparents is in their integration into family relationships and their influence on family climate and background. How Vágnerová (2007, p. 281) stated, that grandparent's role is "biologically conditioned, is non-selective and has a permanent character." Man becomes a grandparent without influencing, and he remains so for the rest of his life, whether he accepts this new role or not. It does not depend only on him, but on his child's will. In the context of demographic changes and shifting of mothers' age at childbirth, today we conversely encounter situations when this transition does not occur. Many individuals in the age, at which they would have expected to take over the grandparental role, do not fulfil these needs. Both situations, of course, have an impact on life quality, on the development of the family system and the identity of the individual and the family.

Grandparents can be a source of learning in basic knowledge, source of inspiration and of instruction in the area of relationships, social interactions (going out with others, the skill of dealing with people), in communication skills, social perception and perception of others and appropriate empathy. Important elements, which grandparents can contribute to generation of children and generation of parents, are also stimulation, emotional support, harmonization and stability of relations. According to Hauser- Schöner (1996, p 61), grandparents can also help in finding the meaning of life. Life seen from their perspective can be a mirror for many everyday situations of younger generations.

For his grandchild, a grandparent may also be a natural pattern, ideal or authority. In the research carried out in 2009, it was found that, for children of all ages, the members of the family were the largest life patterns and they prevailed the other sources of patterns (media, peers, ...) (Stašová,....).

Through contact with generations of grandparents, children can also support the adoption of standards, rituals, traditions and values. Because most of the older generation have more free time, they can also give their grandchildren more of their capacity. Thanks to it, as the Hauser-Schöner (1996, pp. 10-11) says, grandparents give their grandchildren more emotional, time and intellectual capacity. They accompany them in the world of fantasy and games; they are able to put themselves in roles within the different games and they can offer their grandchildren a suitable filling of time during holidays (e.g. Strašíková, 2004, p. 39).

Grandparents can become foster parents and primary educators in the event of a tragedy, deprivation of parental responsibility from the state or in families where the parents cannot give children enough time.

Grandparents can play important role in the economic support of the family (the case of the Czech Republic). De Singly (1999, p. 72) states that "despite the increase of psychologization of the society family, relationships are often rooted in exchanges of goods and services. The power and usefulness of family networks is not opposed to emotional relationships of family groups members, but they can contribute to the creation of new family units and to guarantee a certain degree of their autonomy."

Several generations living together, of course, can also be marked by conflicts. In the case of intergenerational conflicts they reflect not only the personality traits of actors but also some social and cultural factors, by which members of generations are formed. Family as a whole is also a very complex network of family ties that develop all the time. Coexistence of grandparents, parents and children involves tolerance, the skill to listen to each other, to accept rules and the household of individual members, not to interfere with operation and rules of young families (children) and to tolerate their education.

The concept of some situations, moments, relationships, etc. may show considerable differences between generations. This applies to e.g. views on upbringing, on the economy, on education, on 
Int. Conf. SOCIETY. HEALTH. WELFARE.

Table 1. Characteristics of respondents.

\begin{tabular}{|l|c|c|c|c|c|c|}
\hline & 12-13 years & $\%$ & $\mathbf{1 6}-\mathbf{1 8}$ years & $\%$ & Total & \% \\
\hline Girls & 63 & 60.6 & 74 & 75.5 & $\mathbf{1 3 7}$ & 67.8 \\
\hline Boys & 41 & 39.4 & 24 & 24.5 & $\mathbf{6 5}$ & 32.2 \\
\hline Total & $\mathbf{1 0 4}$ & 100 & $\mathbf{9 8}$ & 100 & $\mathbf{2 0 2}$ & 100 \\
\hline
\end{tabular}

spending leisure time, etc. They may arise from unresolved problems and be strengthened with diverse worldviews, intolerance, unwillingness to accept the other's opinion, little or no communication etc. Jirásková states $(2005, \mathrm{p} 26)$ that "the main role is usually played by pre-ocupation of different generations bias towards each other and insisting on the various, even false clichés."

\section{What are the relationships between the generations of children and grandparents currently?}

In our research, which was implemented in 2010, we charted the frequency of grandparents' contact with their grandchildren in contemporary families, in which areas the generation of children and their grandparents face, what topics they speak about and how they evaluate their relationships. We focused on whether there are significant differences between those living with their grandparents in the joint household and those who do not live in the same household. What role does living together play in shaping the relationship between the generations?

In our research, we used quantitative research strategy, a method of questioning. The questionnaire survey contained both closed and open questions. Open questions were then processed qualitatively as well. Respondents were children aged 12-13 years (104 respondents) and young people aged 16-18 years (98 respondents). The sample consisted of respondents attending grammar schools and secondary schools. From this number, there were 137 women (67.8\%) and 65 men (32.2\%). 202 questionnaires were processed in total.

All respondents had grandparents and, usually, they were meeting at least some of them, and they could therefore answer the questions of the research. $44.6 \%$ of respondents had both maternal and paternal grandparents. Other respondents $(55.4 \%)$ had at least one grandparent. $7 \%$ of respondents reported only maternal grandparents, $3.5 \%$ only paternal.

The results showed that $\mathbf{8 7 . 1 \%}$ of respondents were in contact with one of the grandparents. Of the total number of respondents, $12.9 \%$ of respondents had not seen with one of the grandparents. It mostly concerned the respondents from families with the poor father's or mother's relations. It is interesting that the poor relations rather prevailed on their father's side. Only two women- students indicated that they do not see any of their grandparents and the reason for it was long distance (they were foreigners living in the Czech Republic).

38.1\% of the surveyed respondents meet their grandparents every day. The reason of daily contact in most cases they reported a joint household (housing) when they meet every day at home during daily activities. There the respondents also stated that they are in school during the week, and so, although living in the joint household, they meet their grandparents only on weekends. Among other reasons of contact, they stated help to their grandparents, especially in the countryside. And in turn, some grandparents help their grandchildren with preparation for school (homework, tutoring). Other respondents go to their grandparents for lunch after school and wait here for the bus. As shown in Table 2, almost $62 \%$ of the surveyed do not meet their grandparents daily. In one case the womanrespondent living in the joint household with her grandparents argued that she meets them, but they do not communicate to each other.

The surprising fact was that almost half of the surveyed grandchildren have no desire to meet their grandparents more often (47.5\%). $\mathbf{5 2 . 5 \%}$ of respondents would like to see their grandparents 
SHS Web of Conferences

Table 2. Daily contact with grandparents.

\begin{tabular}{|l|c|c|c|c|}
\hline I have a daily contact with ... & $12-13$ years & $16-18$ years & Total & \% of representation \\
\hline No grandparent. & 62 & 63 & $\mathbf{1 2 5}$ & $\mathbf{6 1 . 9}$ \\
\hline 1 grandparent. & 19 & 12 & $\mathbf{3 1}$ & $\mathbf{1 5 . 3}$ \\
\hline 2 grandparents. & 22 & 21 & $\mathbf{4 3}$ & $\mathbf{2 1 . 3}$ \\
\hline 3 grandparents. & 0 & 2 & $\mathbf{2}$ & $\mathbf{1 . 0}$ \\
\hline 4 grandparents. & 1 & 0 & $\mathbf{1}$ & $\mathbf{0 . 5}$ \\
\hline Total & $\mathbf{1 0 4}$ & $\mathbf{9 8}$ & $\mathbf{2 0 2}$ & $\mathbf{1 0 0}$ \\
\hline
\end{tabular}

Table 3. Interest in meeting grandparents more often.

\begin{tabular}{|l|c|c|c|c|}
\hline & $12-13$ years & $16-18$ years & Total & \% \\
\hline Rather yes & 61 & 45 & $\mathbf{1 0 6}$ & $\mathbf{5 2 . 5}$ \\
\hline Rather no & 43 & 53 & $\mathbf{9 6}$ & $\mathbf{4 7 . 5}$ \\
\hline
\end{tabular}

Table 4. The most common way of contact with grandparents.

\begin{tabular}{|l|c|c|c|c|}
\hline Way of communication & $12-13$ years & $16-18$ years & Total & \% of representation \\
\hline Personal contact & 79 & 87 & $\mathbf{1 6 6}$ & $\mathbf{8 2 . 2}$ \\
\hline Via telephone - calling & 19 & 9 & $\mathbf{2 8}$ & $\mathbf{1 3 . 9}$ \\
\hline Via telephone - writing & 1 & 1 & $\mathbf{2}$ & $\mathbf{0 . 9}$ \\
\hline E-mails & 3 & 0 & $\mathbf{3}$ & $\mathbf{1 . 5}$ \\
\hline Writing letters & 2 & 1 & $\mathbf{3}$ & $\mathbf{1 . 5}$ \\
\hline
\end{tabular}

more often. As for age categories, 12-13 year-old grandchildren demanded more frequent contact (see Table 3), which was $58.7 \%$ of them. Among respondents aged 16 to 18 years, it was $45.9 \%$. This is probably due to the age and different interests of these age categories.

Wish to see the grandparents more often understandably prevalent among those respondents who do not live with their grandparents in the joint household $(55.3 \%)$. But even those who live in the same household, are interested in contact more often (44.2\% of respondents).

\section{How do these two studied generations communicate with each other most frequently?}

As the most common way of contact respondents reported personal contact. $82.2 \%$ of respondents in total. The second most frequent contact was by telephone, in $13.9 \%$ of the respondents.

The most common way of spending free time with grandmothers is, according to respondents, chatting (49\%). Furthermore, it is housework and gardening (18\%), watching TV (6\%), shopping (5\%) or something else $(5 \%)$. To the answer other they reported walking the dog, talking about money and playing cards. $3 \%$ of respondents stated spending time with a common hobby. To the response other, variations of activities such as playing cards, nature walks, cooking together, trips, learning on the computer and the Internet, disputations were mentioned.

Leisure time with grandfathers is usually filled with talking (40\%), with watching the television $(7 \%)$, housework and working in the garden $(7.9 \%)$ or a common hobby (4\% of cases). To a lesser extent, they reported walking in the woods and catching fish, computer work, crossword puzzles. In several cases, the children reported that they are not talking much with their grandfather, he keeps quiet, watches TV and he does not even have much interest in spending free time. It can be seen as a positive fact that the majority of respondents spend their leisure time with their grandparents actively. Type of housing (single or joint household) had no influence on the way of spending leisure time. Grandchildren 
Int. Conf. SOCIETY. HEALTH. WELFARE.

Table 5. Patterns in the family.

\begin{tabular}{|l|c|c|c|}
\hline Patterns in the family & $12-13$ years & $16-18$ years & Total \\
\hline Parents & 41.3 & 38.8 & 40.1 \\
\hline Siblings & 8.7 & 4.1 & 6.4 \\
\hline Grandmother & $\mathbf{6 . 7}$ & $\mathbf{6 . 1}$ & $\mathbf{6 . 4}$ \\
\hline Grandfather & $\mathbf{7 . 7}$ & $\mathbf{3 . 1}$ & $\mathbf{5 . 5}$ \\
\hline Someone else & 10.6 & 5.1 & 7.9 \\
\hline Nobody & 25.0 & 42.9 & 33.7 \\
\hline
\end{tabular}

living in the joint household spend their free time with their maternal or paternal grandparents mostly with talking to.

Further, in our investigation, we were interested in what children often speak with their grandparents about when they communicate with them. Most often, maternal and paternal grandmothers talk with their grandchildren about their achievements and skills, $38.6 \%$ of respondents. About hobbies and interests they talk in $15.4 \%$ of cases, about their friends, relatives and people around they talk about in total of $14.4 \%$. Other popular themes in interviews of respondents with their grandmothers were cooking, housework, school, family, friends, animals, as well as talking about news, media (television series, books, magazines), news about life in the neighborhood, health, the needs, the childhood of older generations. The content of communication with grandmothers may be different depending on whether they talk to grandsons or granddaughters. As in this survey female respondents were more prominent, the topics of conversation were rather of feminine character. Grandmothers also tend to be more communicative and are better able to establish (follow up) a dialogue with their grandchildren.

With grandfathers, respondents mostly talk about their achievements and skills in and out of school (26\%), the hobbies and interests (21\%), about friends, relatives and people around (9\%). Then there were technical issues (DIY), sports, garden and animals, history (war, communism), childhood, youth and grandfather's job. Two respondents $(1.0 \%)$ reported that their grandfather do not talk with them and he sits at the television when they are there.

The content of communication of grandmothers and grandfathers with respondents varies. First, it affects the personality of a grandparent as well as family relationships (degree of trust, the interest to confiding, listening to each other and giving each other ear). With the content of communication 41 respondents $(20.3 \%)$ of the total number of 202 are satisfied and they would not change anything. There were, however, respondents who are not satisfied with the content of communication. Of the total number there were 5 (2.5\%) of them. They answered: "I do not want to communicate with them," "We're talking about nothing, they have stupid questions" or "I do not want to talk to them, it just annoys me."

In our investigation we also wonder whether children perceive their grandparents as a pattern. The largest model of the family for the respondents were parents - in $40.1 \%$. A total of 24 respondents (11.9\%) reported grandparents as their pattern. The most frequent reason for this claim they cite grandparents' care for the whole family or what they could do in a lifetime and experienced.

Although respondents did not choose their grandparents for role patterns too much, in many cases, they appreciated them. They admire their grandfathers mostly for, that they are hardworking and skilled, with a lot of fun and have a sense of humor, they are vital and full of enthusiasm, patient and reliable, have a general overview, are optimistic and balanced, nicely talk and always remember them for major events. In most cases they hinder that they can be really upset, they are hothead, they smoke, try to change their grandchildren, they are communists, they are irritable, stubborn, they are still at work, they live far away, they are selfish, angry for little things, do not take things seriously, different opinions, senility, outdated and old-fashioned views. 
SHS Web of Conferences

Table 6. Results of the evaluation of the quality of relationships with family members (in \%).

\begin{tabular}{|l|c|c|c|c|c|}
\hline Variants of answers & Very good & Rather good & Rather bad & Very bad & $\begin{array}{c}\text { I do not have this } \\
\text { family member }\end{array}$ \\
\hline Mother & 64.4 & 30.7 & 5.0 & 0.0 & 0.0 \\
\hline Father & 47.5 & 35.6 & 10.4 & 6.4 & 0.0 \\
\hline Sibling & 46.5 & 30.2 & 8.4 & 5.0 & 9.9 \\
\hline Maternal grandmother & $\mathbf{5 6 . 9}$ & $\mathbf{2 4 . 8}$ & $\mathbf{8 . 9}$ & $\mathbf{1 . 5}$ & $\mathbf{7 . 9}$ \\
\hline Maternal grandfather & $\mathbf{3 3 . 7}$ & $\mathbf{2 8 . 7}$ & $\mathbf{7 . 9}$ & $\mathbf{2 . 0}$ & $\mathbf{2 7 . 7}$ \\
\hline Paternal grandmother & $\mathbf{3 2 . 2}$ & $\mathbf{3 6 . 1}$ & $\mathbf{9 . 4}$ & $\mathbf{6 . 9}$ & $\mathbf{1 5 . 3}$ \\
\hline Paternal grandfather & $\mathbf{2 2 . 8}$ & $\mathbf{2 7 . 7}$ & $\mathbf{1 3 . 4}$ & $\mathbf{4 . 0}$ & $\mathbf{3 2 . 2}$ \\
\hline Other relatives & 29.7 & 55.9 & 11.4 & 3.0 & 0.0 \\
\hline
\end{tabular}

The grandmothers are appreciated with the fact that they are worthy, kind, caring, hard-working, dedicated, ambitious, friendly, patient, vital, wise, inventive, funny, they also know how to cook, take care of the household, they know how to sew, they always know what to do, read a lot, have a positive view of the world, allow things that parents do not allow, buy their favourite sweets. One respondent stated that she appreciates her grandmother because she is a "good mother of her parents." The respondents do not like when their grandmothers impose their views, they are old-fashioned, some smoke, they are pessimistic, still talking to the respondent as being a child, they are nervous, too talkative, they force to do the housework, all the time they talk about school or diseases. The negative characteristics that children evaluate: excessive solicitude, hypersensitivity, sclerosis, listening to brass bands, exaggerating the facts, not respecting privacy, troubleshooting and forcing to eat.

It turned out that the way of housing had no effect on admiration or criticism of grandparents.

Intimacy of the relationship we tried to measure by how often the children entrusted to these family members. It turned out that grandparents are often entrusted to $5 \%$ of the respondents $(4.5 \%$ of children to grandma, to grandpa $0.5 \%$ ). The surprise was that almost $9 \%$ of respondents stated that they do not confide anyone. This may be due to the nature of an individual or disrupted family relationships. It seemed that children have a tendency to confide grandparents when they do not live with them in the household. With trouble at school $6.9 \%$ of respondents entrust their grandmother, while $3 \%$ of personal problems and problems with friends also $3 \%$. In these particular issues the communication partners of children were only grandmothers, grandfathers were not disclosed. Regarding the degree of confidence in the problems in terms of type of housing (single or joint household), the results showed that it is not possible to find a larger difference. Grandmothers rather entrust the grandchildren living apart (problems with school and friends), on the contrary, grandchildren living in the same household entrusted with personal problems more often.

At the end of the investigation, we asked how children evaluate their relationships with grandparents in terms of relationships, communication and trust. When we watched the relationships with relational lines as a whole, it seemed that respondents have a better relationship with the maternal grandparents than paternal. They also expressed more critically to their fathers and vice versa they had better relationships with their mothers. It could be assumed that the relationship with parents may also affect the relationship with grandparents as well.

\section{Conclusion}

There are many changes going on in the society. The centre of gravity of social status is increasingly concentrated in the younger age groups, whose members are able to meet the current ideal of youth, beauty and success. Society requires and encourages young, attractive, promising (perspective), flexible 


\section{Int. Conf. SOCIETY. HEALTH. WELFARE.}

people, and also with its services it focuses more on them than on the older generation. The development of new technologies is opened for young people and older people have worse interaction with them.

The results of our investigation as well as many others, however, show the potential of intergenerational cohabitation which it contains.

The results of the research survey proved that the difference between respondents living in the joint household and in a separate household was not essential. We cannot therefore conclude that living together also means better relationships with grandparents and bigger trust in them, we did not appear the influence on leisure time, the intensity of the relationship and trust to grandparents. Modern communication technologies enable intensive contacts between generations even in a separate housing. Grandchildren appreciate their grandparents and in most cases they are glad to have them and they realize that thanks to them they have learned many things.

\section{References}

[1] De Singly, Francois. Sociologie současné rodiny. 1. vyd. Praha: Portál, 1999. 128 s.

[2] ISBN 80-7178-249-1

[3] Hauser-Schöner, Isabella. Děti potřebují prarodiče. 1. vyd. Praha: Portál, 1996. 104 s.

[4] ISBN 80-7178-105-3

[5] Höpflinger, Francois. Grosseltern in einer dynamischen Gesellschaft - Wie erleben Enkelkinder und Grosselten diese Beziehung? [cit. 20. 2. 2010]. Př́stup z:

[6] http://www.nfp52.ch/d_dieprojekte.cfm?Projects.command=details\&get=13

[7] Jirásková, Věra a kol. Mezigenerační porozumění a komunikace. 1. vyd. Praha: Eurolex Bohemia, 2005. $198 \mathrm{~s}$

[8] ISBN 80-86861-80-5

[9] Strašíková, Blanka. V roli rodičů a prarodičůu. 1. vyd. Praha: Karolinum, 2004. 58 s

[10] ISBN 80-246-0848-0

[11] Vágnerová, Marie. Vývojová psychologie II. Dospělost a stáří. 1. vyd. Praha: Karolinum, 2007. $461 \mathrm{~s}$

[12] ISBN 978-80-246-1318-5 